\title{
Comparing and Discussing Positions on Scientific Literacy in Teacher Education and Lower Secondary School Curricula
}

\author{
Gerd Johansen \\ Norwegian University of Life Sciences, Norway \\ Hilde Wågsås Afdal \\ Østfold University College, Norway
}

\begin{abstract}
One of the purposes of science teacher education is to provide prospective teachers with a solid foundation from which to educate scientifically literate pupils. It is reasonable to assume that curriculum documents provide opportunities as well as imposing restraints on the interpreted, enacted, and experienced curriculum. Hence, we analyse Norwegian national curricula documents for science teacher education and lower secondary education to explore how they communicate in terms of positions on scientific literacy: we explore how knowledge, knowledge processes, and values related to knowledge are configured in the documents. Our analysis is a theoretically driven content analysis inspired by discourse analysis, through which we explore the configuration of the concepts and arguments in use in the curricula. Although both curricula emphasize a similar body of knowledge, the teacher education curriculum lacks the more elaborate approaches to communication and the nature of science (NOS) that are found in the school science curriculum. Moreover, both are concerned with science as enculturation but otherwise provide different arguments for learning science. Prospective teachers might thus be ill-equipped to address vital epistemic aspects of school science.
\end{abstract}

Keywords: Curriculum analysis; Science (teacher) education; Science curriculum; Scientific literacy; Curriculum structures.

\section{Introduction}

One of the main functions of teacher education is to prepare prospective teachers to work with increasingly diverse students and complex content (DarlingHammond, 2006). Teacher education should provide prospective teachers with a solid foundation for negotiating epistemologically between their own educational background and the aims of their teaching enterprise. To explore how teacher education is related epistemically to school content, we analyse 
curricula documents. Our point of departure is not that the content of teacher education should be completely aligned with school curricula content in regard to the epistemic dimension, and we acknowledge that a curriculum, as a document, differs from what is actually taught and learned (Goodlad, 1979; Melville, 2008). In line with Wallace's (2012) argument, it is reasonable to assume that a curriculum document creates possibilities and imposes restraints on the interpreted, enacted, and experienced curriculum. Furthermore, there is a need to inspect the design of teacher education programs and how they "add up to a set of knowledge, skills and dispositions that determine what teachers actually do in the classroom" (Darling-Hammond, 2006, p. 303). Young (2013) argues that past curriculum studies have paid more attention to who defines knowledge (the political dimension) rather than exploring the distinct characteristics and arrangements of knowledge in curricula documents (i.e. the epistemic dimension).

In this article, we explore how science teacher education and school science communicate in terms of their positions on scientific literacy: how knowledge, knowledge processes, and values related to knowledge are configured in curricula documents. Scientific literacy has been used as an umbrella term to describe the objective of science education; this term has the potential to conflate different positions, including in the epistemic dimension (Roberts, 2007; Sadler \& Zeidler, 2009). There is substantial political interest in the importance of scientific literacy for securing productivity in knowledge-intensive sectors and ensuring that citizens can utilize scientific and technological information and participate in science-related societal issues (European Parliament Council of the European Union, 2006; Eurydice Education Audiovisual and Culture Executive Agency, 2011; Kunnskapsdepartementet [Norwegian Ministry of Education and Research], 2015; National Research Council, 2012); Organisation for Economic Co-operation and Development, 2012b). However, in many countries, there has been concern that school science does not sufficiently educate students in scientific literacy (e.g., OECD, 2012a, 2016), and teacher education is seen as playing an important role in addressing this problem (Eurydice Education Audiovisual and Culture Executive Agency, 2011). With reference to policyreports, Cochran-Smith and Villegas (2015) pointedly write, "Teachers matter, not just in the classroom but in terms of a nation's economy" (p. 9).

\subsection{Aim and research questions}

The aim of this article is to explore whether the positions on scientific literacy included in a teacher education curriculum could lay the foundation for prospective teachers to develop students' scientific literacy. To demonstrate what an analysis of the epistemic dimension of curricula might look like, we consider Norwegian science teacher education and the related compulsory school science curriculum. Curricula documents express intentions about the selection of content, activities, and ways of measuring learning outcomes. Knowledge is chosen, organized, and structured in different ways depending on the discipline(s), the stakeholders in the development process, and the context in which the document is developed. Therefore, we argue that the epistemic 
dimensions of curricula must be investigated empirically. We presume that such an analysis will be favourable and relevant in many contexts.

To enable an investigation of the epistemic dimensions of the related curricula, and specifically of scientific literacy, we ask the following research question: What epistemic alignments and tensions exist within and between the related curricula? The documents that we analyse are The National Guidelines for Differentiated Teacher Education Programs: School science, grades 5-10 (Kunnskapsdepartementet [Norwegian Ministry of Education and Research], 2011) and The Curriculum for School Science, grades 5-10 (Utdanningsdirektoratet [Norwegian Directorate for Education and Training], 2013).

\section{The epistemic dimension of science teacher education}

When student teachers enter teacher education programs, they usually have a set of taken-for-granted assumptions about science, teaching, and learning (Loughran, 2014). Moreover, student teachers believe that they need to learn "science activities that work," a rather instrumental approach that might actually confound their understanding of students' learning of science. Furthermore, practical activities are particularly difficult to manage while ensuring students' learning, and thus student teachers must develop confidence in their handling of such activities (Appleton \& Kindt, 2002). In science education research, it is hoped and expected that "science teaching as telling" and "activities that work" will be challenged (Loughran, 2014) and replaced with principles and big ideas in science (Collins et al., 2000; Harlen, 2010) and science practices (National Research Council, 2012).

Davis, Petish, and Smithey (2006) state, with reference to several previous studies, that "preservice teachers seem, for the most part, to lack adequate understanding of science content" (p. 615). In an interview study of preservice teachers' understandings of evolution in relation to climate change, Thomson and Tippins found that the teachers had developed partial and fragmented understandings, suggesting lack of an interdisciplinary approach to science content in teacher education (Thomson \& Tippins, 2013). Knowing content is necessary but not sufficient for good teaching (Osborne, 2014). It is challenging to both become proficient in science and learn to teach it: "Put most simply, science cannot be learned - or taught-in the absence of its discourse. Similarly, we contend, how we teach science cannot be learned - or taught -in the absence of educational discourse" (Russell \& Martin, 2014, p. 886). In other words, science teacher education needs to draw upon knowledge and skills from very different disciplinary fields. If, during their teacher education, student teachers do not experience the complexities of handling student-centred ways of working, such as inquiries or discussions of scientific controversies, it is not likely that they will implement such activities in their own classrooms (Bianchini, 2012). Thomson and Tippins (2013) argue that science teacher programs need to prepare prospective teachers in the twenty-first century with regard not to "what to think" but rather "how to think" as decision makers. 


\section{Analytical framework}

Before we present the outcome of the analysis, we provide a framework for how we approach the logics and arrangements of knowledge in curricula (the epistemic dimension). Further, we elaborate on scientific literacy as a domainspecific configuration of the epistemic dimension. Finally, we present curriculum structures as a classification scheme for approaching scientific literacy in the documents analytically.

\subsection{Approaching the epistemic dimension in curricula}

Curricula emerge from the struggle between competing stakeholders with different biases and foci (Bernstein, 2000; Fensham, 2013), resulting in prominence of some positions and not others. Curricula normally present a set of experiences and activities that should be included, a selection of content from specific discipline(s), and ways of measuring knowledge and success (see Lattuca and Stark's [2009] "academic plan"). Curricula-related documents also contain logics and arrangements for how knowledge comes into being and how it is approached and communicated. The variations in these different components give the field its distinctive character (Lattuca \& Stark, 2009). Phenix (1986) argued that traditional disciplines represent a natural ordering of knowledge and thus provide certain appropriate organizing principles for curricula. We, on the other hand, agree with Muller (2009) that there is no straightforward relationship between disciplinary knowledge and curricular knowledge, particularly with regard to trans-disciplinary courses and professional programs, such as school science and science teacher education. A re-contextualization of knowledge always occurs (Bernstein, 2000). Knowledge is reorganized and restructured in different ways depending on discipline(s), actors, and contexts. The epistemic dimension of curricula will be distinct for specific educational domains and thus should be investigated empirically.

\subsection{Scientific literacy}

Although scientific literacy is a term that has been used for many decades, it has no uniform definition. Indeed, the terms "science literacy" and "scientific literacy" are used interchangeably, and there is no general agreement on which one should be used (Roberts, 2007). The discussion of scientific literacy in curricula is fundamentally a discussion of what knowledge to select and how to approach and communicate that knowledge in science.

Roberts (2007) uses the terms "Vision I" and "Vision II" to elucidate what it means to be literate in science. Vision I is so "named because the image of the student as novice scientist was probably the earliest guide to plan precollegiate school science" (Roberts \& Bybee, 2014, p. 546). Knowledge and skills are associated with the education of future scientists (Roberts \& Bybee, 2014) and might be connected to the traditional body of knowledge (the canon) and (traditionally) to a more implicit approach to knowledge, particularly with regard to the processes and methods of producing scientific knowledge-in other words, the nature of science (NOS). An alternative vision (Vision II) 
connects societal issues and individual life situations in which persons use scientific knowledge. These issues might be controversial, and they might entail economic, political, or ethical considerations. Thus, Vision II emphasizes (practical) problem solving, scientific inquiries, and an explicit approach to NOS. The combination of processes in science and NOS makes it possible for one to learn about the epistemic practices of science, which address aspects such as assessment, inference from observations, the role of models, and the truth-value of statements (Lederman \& Lederman, 2012).

Drawing on the term Science-Technology-knowing-in-action (Aikenhead, Orpwood, \& Fensham, 2011), Liu (2013) expands Roberts' visions with a Vision III. This vision, also called scientific engagement, "promotes active participation in debate and seeking solutions on today's pressing issues facing the world" (Liu, 2013, p. 28). Such issues might be environmental problems or challenges that society faces because of technological development. Similar views are expressed by Mogensen and Schnack (2010) through their concept of "action competence," whereby students are taught to address interdisciplinary issues in a participatory and democratic manner without losing sight of the importance of disciplinary knowledge. Moreover, Vision III advocates permeability between school science and informal science learning. Liu depicts the three visions as partly overlapping circles. All share some core elements, as they have some shared content-however, the weightings of "the body of knowledge," "science processes," 1 "NOS," and "action competence" vary extensively among the three visions.

Hodson (2003) presents an analytical classification of four elements of a scientific literacy curriculum, as follows: (a) The body of knowledge is composed of concepts, laws, and theories - that is, traditional textbook knowledge. There are many different arguments regarding the necessary extent and depth of teachers' bodies of knowledge. (b) Processes and methods in science relate to skills, such as investigating and measuring phenomena, and are vital for "doing science." The methods of such investigations vary among scientific disciplines. (c) Learning about science relates to knowledge of how and why scientific knowledge is produced-in other words, the epistemology or nature of science (NOS). Most research recommends that NOS should be explicitly addressed during scientific inquiries (Abd-El-Khalick, 2011). Students' understanding of NOS is fundamental if they are to have any sense of the complexities and social embeddedness of the production of science (Smith \& Gunstone, 2009). (d) Action competence, or being able to take action, is about empowering students to engage with topics such as local and global technological or environmental issues. However, it is important to note that this is not intended to be "indoctrinating" or "moralistic;" rather, it is intended to enable students to deliberate and discuss interdisciplinary knowledge, various interests, and ethical

\footnotetext{
${ }^{1}$ Science processes refers to the practical part of science- "doing science." There are different traditions concerning how to approach doing science, such as practical work (Hofstein \& Kind, 2011), inquiry (Duschl \& Grandy, 2008), or scientific practices (National Research Council, 2012), with subtle differences that are beyond the scope of this article.
} 
issues and, on this basis, take well-reasoned actions as citizens (Hodson, 2011; Mogensen \& Schnack, 2010; Sund \& Öhman, 2014).

To sum up, the content of science curricula can be seen as a body of knowledge, processes, NOS, and action competence. Different combinations of these constitute the different visions of what the objective of science education - that is, scientific literacy - ought to be. These visions are, however, will not be found in pure form in a curriculum (Roberts, 1988; Roberts \& Bybee, 2014). Curricula, as political documents, can be somewhat ambiguous. Issues such as how the science subject matter is seen and how it is dealt with are both implicitly and explicitly formulated in curricular documents (Roberts, 1988).

\subsection{Approaching scientific literacy through curriculum structures}

According to Lattuca and Stark (2009), traditional classification schemes of the epistemic dimension of disciplines do not take into account the specialized epistemic character of professional fields. They therefore elaborated and expanded upon the traditional schemes in such a way that they are also applicable to developing or examining the epistemic dimension of professional curricula. Building on Dressel and Marcus (1982) and Phenix (1986), Lattuca and Stark (2009) further developed the former scholars' notion of the "natural ordering of knowledge" to also take into account the special characteristics of professional fields by retaining the names of the original five components or structures of curricula-organizational, substantive, symbolic, syntactical, and value structure. We use Lattuca and Stark's components as a classification scheme and develop a hybrid form between the strict discipline-based classification and Lattuca and Stark's more profession-oriented scheme. The reason for this is that whilst the bulk of curricula focus on knowledge and skills based on scientific disciplines, teacher education also draws on the field of science education. The school science curriculum and the school context comprise the "professional field" toward which the teacher education curriculum is oriented. This approach to the field of science education will reveal information on what is seen as important to engage with and how to engage with it. We have operationalized the curriculum structures in our analysis as follows:

- Organizational structure addresses how disciplines are organized and related to each other within the curriculum, thus revealing prioritized knowledge.

- Substantive structure concerns the actual knowledge and skills included in the curricula.

- Symbolic structures address vocabulary and representational forms. The symbolic structure of science also implies genres, concepts, and systems of classification (Halliday, 2004) in addition to representations such as written and spoken words and visual models. Working with information in different representations and translating between them (e.g. verbalizing information presented in a graph) is important for communicating subject matter precisely and efficiently (Knain, 2015). Genres such as descriptions and explanations play a vital role in science education (Braaten \& Windschitl, 2011; Veel, 2000). 
- Syntactical structure involves the approaches used to address the substance of the courses, meaning the type of approaches used to describe knowledge work and knowledgeability and how knowledge is constructively and critically validated. This part of the framework will be described in more detail in the forthcoming analysis.

- Value structure involves scrutinizing various ways of viewing the nature of knowledge and what is worth learning and why. According to Corrigan, values in curricula appear as "very often implicit and often not even recognized by those developing the curriculum" (Corrigan, 2014, p. 1). This analysis will elucidate both explicit and implicit values embedded in the two curricula.

We see the five structures as analytical categories, not as separate empirical entities. The amalgam of the five components provides an opportunity to discuss positions on scientific literacy.

\section{Methodology}

This study employs a qualitative and comparative research approach to curricula documents. Based on the curriculum structures elaborated above, we conduct a theoretically driven content analysis. The analysis is also inspired by Fairclough's (2003) discourse analysis because we study the way curricula are shaped through the configuration of concepts and arguments in useparticularly the analysis of syntactical structure. In a first reading, two documents can appear to be epistemically aligned. However, by using an iterative approach based on our operationalization of curriculum structures, nuances within and between the documents appear.

We begin with rather flat descriptions of the organizational and substantive structures in order to provide an overview of the documents. Then, we proceed to a somewhat more detailed analysis of symbolic structures, especially of syntactical structures, approaching expressions, formulations, and the use of concepts in more detail. In the analysis of value structures, we seek to illuminate the explicit and implicit value discourses in the documents and across the first four curriculum structures.

Excerpts are chosen based on two criteria: (a) they are representative across the document or (b) they represent something singular. In the analysis, we use the term "pupil(s)" for students in grades 5-10, consistent with the school science curriculum document, and we use the term "student(s)" for student teachers. We underscore that such an analysis does not provide information about the how the curricula are enacted in particular educational settings.

The following abbreviations reoccur throughout the presentation of the findings:

- NOS: Nature of science

- TEC: The science teacher education curriculum (grades 5-10)

- SSC: The school science curriculum (grades 5-10) 


\section{Findings}

This section begins with a presentation of the documents and the context in which they were developed. The analysis proceeds by presenting the findings for each of the five curriculum structures in separate sections. Finally, positions on scientific literacy expressed in the documents are compared.

\subsection{The context and the documents}

The documents we chose to analyse are The National Guidelines for Differentiated Teacher Education Programs (Kunnskapsdepartementet [Norwegian Ministry of Education and Research], 2011), hereafter called TEC, and The Curriculum for School Science (Utdanningsdirektoratet [Norwegian Directorate for Education and Training], 2013), hereafter called SSC. TEC makes up one section in the National Guidelines for Differentiated Teacher Education Programs and is covered in five pages (pp. 65-69). SSC covers compulsory school science and is 12 pages in its entirety. We have analysed the common parts of SSC as well as the competence aims for grades 5-10. Though the analysed documents are short in terms of number of pages, they are dense in information and meaning.

Science teacher education can take various forms-for an overview, see, for example, Olson, Tippett, Milford, Ohana, and Clough (2015) - and Norway is no exception. There are teacher education programs for grades 1-7, 5-10, and 8-13. These programs have different balances among science subject matter, pedagogy, and professional knowledge. TEC is part of the Differentiated Teacher Education Program for grades 5-10. It is a four-year program that was implemented in the fall of 2010, and it can be characterized as a major reform. The program contains 60 credits (ECTS 2 ) in pedagogy and professional knowledge as well as three elective courses, one of which can be science. Teacher education institutions can freely organize the courses and determine, for instance, the duration of courses, specific assignments, and types of exams. Teacher education programs have no formal admission requirements with regard to science; student teachers may enter these programs if they have taken compulsory school science courses.

In Norway, school science is a compulsory subject from grades 1-11. It is a transdisciplinary subject area that integrates physics, chemistry, biology, geo-science, and technology, and science class is taught by one teacher. SSC was implemented in 2006 as part of a reform called "Knowledge Promotion," and it was revised in 2013. The subject is taught 2-3 hours a week in grades 5-10. To be formally qualified to teach science to pupils in grades $8-10$, teachers should have a minimum of $30 \mathrm{ECT}$ credits in science. There is no such requirement for teachers of younger pupils.

Governmental bodies are responsible for the creation of Norwegian curriculum documents (e.g. through appointed groups of experts). TEC and SSC are developed separately, and both are legally binding for their respective

\footnotetext{
${ }^{2}$ European Credit Transfer and Accumulation System.
} 
educational systems. These documents instruct teacher education institutions and schools/local governments in producing institutional curricula and teaching and learning plans as well as performing assessments in close alignment with these documents. It is expected that the school science curriculum (SSC) is taught and discussed in teacher education; however, the structure and the content of teacher education must be developed based on TEC.

\subsection{Organizational structures}

Organizational structure addresses how knowledge areas are prioritized and related to each other within the curriculum. An overview of the organization of the two curricula is displayed in Table $1^{3}$.

Table 1. Outlines of the two curricula

\begin{tabular}{|c|}
\hline SSC \\
\hline Purpose \\
\hline \begin{tabular}{ll} 
& \multicolumn{1}{c}{ Main Subject Areas: } \\
- & The Budding Researcher \\
- & Diversity in Nature \\
- & Body and Health \\
- & Phenomena and Substances \\
- & Technology and Design
\end{tabular} \\
\hline Teaching Hours \\
\hline $\begin{array}{l}\qquad \text { Basic Skills } \\
\text { (Oral expression, writing, reading, numeracy, } \\
\text { digital skills) }\end{array}$ \\
\hline $\begin{array}{l}\text { Competence Aims } \\
\text { Elaborated on after grades } 2,4,7,10 \text {, and } 11\end{array}$ \\
\hline $\begin{array}{l}\text { Subject Assessment (final assessment) } \\
\text { (After grade 10: overall achievement grade } \\
\text { and possible oral exam) }\end{array}$ \\
\hline
\end{tabular}

\begin{tabular}{|l|}
\hline \multicolumn{1}{|c|}{ TEC } \\
\hline \multicolumn{1}{|c|}{ The subject in teacher education } \\
\hline Science 1 (30 ECTS) \\
Presentation of Subject \\
Learning Outcomes \\
- $\quad$ Knowledge \\
- $\quad$ Skills \\
- General Competencies \\
\\
\hline Science 2 (30 ECTS) \\
Presentation of Subject \\
Learning Outcomes \\
- Knowledge \\
- Skills \\
- General Competencies \\
\end{tabular}

SSC consists of the introductory sections common to grades 1-11. These sections are Purpose, Main Subject Areas, and Basic Skills and are presented as running text. Broadly, these sections address what science is, why it is necessary to learn science, how to work with and express science, and attitudes toward science. The document also contains minimum norms for how many teaching hours pupils are required to have. The main section contains a list of bullet points that include the competence aims elaborated on after grades $2,4,7,10$, and 11 . This provides schools with a choice about which aims should be addressed in which year. There is, to some extent, an explicit vertical organization of knowledge in the competence aims. For instance, after grade 7, pupils are to "converse about why it is important to make and test hypotheses" (SSC, p. 9), whereas after

${ }^{3}$ All the quotes from the curricula have been translated by the authors. 
grade 10 , they are to make their own hypotheses (see Table $2 b$ ), as creating and supporting a hypothesis is a more demanding task. At the end of the document, there is a section presenting the final assessment. Formative assessment is not specified.

As Table 1 shows, TEC has a quite different organization. The introduction, presented as running text, broadly addresses teaching school science and how science is viewed. After the common introduction, the two modules (Science 1 and Science 2) are presented. The two modules have detailed descriptions of learning outcomes in the form of bullet points, which are divided into the headings Knowledge, Skills, and General Competencies based on the Norwegian Qualification Framework (NQF; TEC, 2009). TEC does not specify that Science 1 must be completed before Science 2; there is no obvious progression, either explicit or implicit. However, all the learning outcomes related to "body and health" are included in Science 2, meaning that if a student takes only Science 1, that teacher education will not cover human biology, but he or she will still qualify to teach grades 5-10. Further, the introduction to Science 2 states that "Science 2 supplements Science 1, and together they shall provide a foundation to give [the student] subject matter confidence in the whole of the subject" (TEC, p. 67). TEC's implicitly indicates that students will have the necessary knowledge and skills to teach grades 5-10 if they complete both Science 1 and Science 2.

In summary, both documents have introductory sections that address overarching positioning on science and learning. Knowledge in science is grouped primarily according to scientific disciplines. There is a textual division between introductory sections (running text) and the description of aims and learning outcomes (bullets) in both documents. Concerning aims and outcomes, SSC is partly vertically organized, whereas TEC is organized horizontally. If these documents were leaning toward visions II and III, one might expect them to be organized along the principles of themes or contextualization.

\subsection{Substantive structures}

Substantive structure involves the selection of knowledge. Due to the organizational structures of both documents, the presentation is divided between introductory sections and competence aims/learning outcomes.

Introductory parts of the curricula. In SSC, the Purpose states that even if the knowledge fields that school science builds upon are "biology, physics, chemistry, and geo-science subjects, the aim is that natural science shall appear as a holistic school subject, both theoretically and practically" (SSC, p. 1). Scientific disciplinary knowledge is to be integrated or presented so that it provides coherence. The above excerpt states that the subject matter encompasses both the body of school science knowledge and conducting school science processes. School science is structured into five main subject areas (see Table 1). The Budding Researcher is special, as it is supposed to be integrated into all other main areas. "Teaching in natural science presents natural science as both a product that shows the knowledge we have acquired thus far in history 
and as processes that deal with how knowledge of natural science is developed and established" (SSC, p. 2). In other words, The Budding Researcher addresses NOS in addition to processes.

TEC's introduction, The Subject in Teacher Education, identifies science subject matter and didactics ${ }^{4}$ (science education) as the two main content areas: "The subject shall provide subject matter and a didactical foundation to teach science in grades 5-10" (TEC, p. 65). The introduction also states that the course should be closely related to the field of practice (science education in schools) and be research-based. Moreover, "The education shall provide experiences with diverse ways of working and didactical reflection that prepare for a teacher role that encourages pupils' learning and development of basic skills" (TEC, p. 65), implying that there is a broad and integrated selection of knowledge and skills. The disciplinary scientific knowledge is identified as biology, physics, chemistry, geo-science, astronomy, and technology.

Competence aims/learning outcomes. In SSC, each aim is assigned a main subject area and begins with the formulation "The aims of the studies are to enable pupils to ...". There are 35 aims, in total, for grades 8-10, and 27 for grades 5-7. Most of the competency aims explicitly incorporate elements of basic skills and/or the Budding Researcher. Most of the competence aims are compound, containing more than one learning objective (see examples in Table 2a). The SSC subject matter is organized into five main subject areas (see Table 1), which clearly show a coupling with traditional science disciplines. Most of the aims refer to established knowledge in science-as seen in the aims of ecology and electromagnetism in Table 2a, for example.

Table 2a. Examples of competency aims and learning outcomes

\begin{tabular}{|l|l|l|}
\hline Example of & $\begin{array}{l}\text { SSC } \\
\text { The aims of the studies are to } \\
\text { enable pupils to... }\end{array}$ & $\begin{array}{l}\text { TEC } \\
\text { The student... }\end{array}$ \\
\hline Ecology & $\begin{array}{l}\text { describe the characteristics of } \\
\text { some plants, mushrooms, and } \\
\text { animal species and put them in } \\
\text { systematic order } \\
\text { (Diversity, after grade 7) }\end{array}$ & $\begin{array}{l}\text { is acquainted with names, traits, and } \\
\text { characteristic features of some } \\
\text { common species of organisms } \\
\text { (Science 1) }\end{array}$ \\
\hline Energy & $\begin{array}{l}\text { elaborate on the use of some } \\
\text { sources of energy, past and } \\
\text { present, and gather information } \\
\text { and statistics from different } \\
\text { sources to describe the possible } \\
\text { local and global consequences for } \\
\text { the natural environment when } \\
\text { using such energy }\end{array}$ & $\begin{array}{l}\text { has extensive knowledge about } \\
\text { and renewable and non-renewable } \\
\text { sources of energy }\end{array}$ \\
\hline
\end{tabular}

4 The term "didactics" is used to refer to deliberations on both the practical and theoretical aspects of why, what, and how to teach as well as whom (see e.g. Hopmann, 2007). However, in this article, we choose to use the term "science education." 


\begin{tabular}{|l|l|l|}
\hline & $\begin{array}{l}\text { (Phenomena and Substances, } \\
\text { after grade 7) }\end{array}$ & \\
\hline Environment & $\begin{array}{l}\text { to enable the pupil to observe } \\
\text { and provide examples of how } \\
\text { human activities have affected a } \\
\text { nature area, investigate the views } \\
\text { of different interest groups on } \\
\text { these effects and propose } \\
\text { measures that might preserve } \\
\text { nature for future generations } \\
\text { (Diversity, after grade 10) }\end{array}$ & $\begin{array}{l}\text { int be changed over time as a } \\
\text { rinterventions, and consequences for } \\
\text { biological diversity } \\
\text { (Science 1) }\end{array}$ \\
\hline $\begin{array}{l}\text { Electro- } \\
\text { magnetism }\end{array}$ & $\begin{array}{l}\text { carry out experiments with } \\
\text { magnetism and electricity and } \\
\text { explain and present results } \\
\text { (Phenomena and Substances, } \\
\text { after grade 7) }\end{array}$ & $\begin{array}{l}\text { has knowledge about basic } \\
\text { magnetism, electronics, electricity, } \\
\text { and the electrical energy supply } \\
\text { system and knows about relevant } \\
\text { experiments and simple calculations } \\
\text { (Science 2) }\end{array}$ \\
\hline
\end{tabular}

However, SSC has competence aims that explicitly go beyond the canon (see the aims on energy and environment in Table 2a). These two aims also serve as examples of science-related issues in society. The example of the aim of the environment section to "propose measures" might be interpreted as requiring action competence. Table $2 \mathrm{~b}$ provides examples of the extensiveness of the aims of The Budding Researcher. SSC is quite ambitious concerning how to address science as a process and NOS.

Table $2 \mathrm{~b}$. Examples of competence aims and learning outcomes concerning processes and NOS

\begin{tabular}{|l|}
\hline Competence aims in SSC-The Budding Researcher, grade 10 \\
\hline - \\
formulate testable hypotheses, plan and undertake hypothesis testing, and discuss \\
observations and results from trials in a report \\
gather and process natural science data, perform calculations, and present the results in a \\
graphical manner \\
write explanatory and argumentative texts with references to relevant sources, evaluate the \\
quality of one's own texts and those of others, and make appropriate revisions \\
- $\quad$ explain the importance of looking for relationships between cause and effect and explain \\
why argumentation, disagreement, and publication are important in natural science \\
identify scientific arguments, facts, and assertions in texts and visual information from \\
newspapers, brochures, and other media and evaluate the content of these in a critical \\
manner \\
(SSC, p. 10) \\
Learning outcomes in TEC \\
- have knowledge about scientific methods and ways of thinking \\
have knowledge about reasons for uncertainty and errors in measurement and results and \\
how these are assessed and handled \\
be acquainted with examples of how science has developed throughout history \\
(TEC, pp. 66-68)
\end{tabular}


To be able to achieve the aims in Table $2 \mathrm{~b}$, pupils need to explicitly understand certain aspects of NOS, such as the difference between descriptions and various forms of explanations, as well as arguments in which empirical data interplay with theory. Planning an investigation involves formulating scientific questions, creating hypotheses that can be tested, assessing equipment, and creating a procedure.

TEC has descriptions of learning outcomes that mostly "match" the phenomena in SSC (see Table 2a). The aim of the ecology section in Table 2a requires, however, an interpretation of how many "some" is and what "common species" are. Those selections will require deliberation, which is not demanded of the students in TEC. The examples from Table $2 \mathrm{a}$ on environment and, especially, on energy, deviate from their counterparts in SSC, as they place less emphasis on science-related issues in society. This is a common trait in TEC learning outcomes.

For both Science 1 and Science 2, skills and general competencies are primarily traditional didactical aspects of teaching, such as making teaching plans, facilitating learning, and assessing pupil knowledge. In addition, some aspects are specifically connected to science education, such as the use of equipment, models (physical and visual), practical work, and the use of scientific knowledge in conversations with pupils. Two learning outcome descriptions involve everyday concepts (i.e. pupils' descriptions and explanations of phenomena that are contrary to established science), and there is emphasis on changing these everyday concepts so that pupils' perceptions of scientific phenomena become more aligned with the scientific story. For instance, students should "have strategies to uncover and possibly alter pupils' everyday concepts" (TEC, p. 67).

Themes that are visible in SSC but not made explicit in TEC include being able to conduct inquiries and open-ended discussions, including aspects such as inference from observations and assessment of truth-value, in the classroom. This discrepancy is presented in Table $2 b$, which presents all the learning outcomes in TEC concerning processes in science and NOS, as well as the aims after grade 10 in SSC.

In summary, the introductory sections of both curricula emphasize the integration of the listed disciplines of science. This can be read as an opportunity for more context-based science education (Visions II and III). Additionally, TEC specifies the integration of didactical knowledge and skills. However, the learning outcomes mostly concern disciplinary knowledge and skills. Didactics is presented as a separate outcome. Both curricula emphasize the learning of an established body of knowledge (the canon) and deal mainly with the same phenomena. However, there is a discrepancy between TEC and SSC with regard to NOS and science-related issues in society. TEC leans more toward Vision I than does SSC, while also incorporating elements that can be labelled Vision II. SSC has one aim that includes action competence, i.e. Vision III. 


\subsection{Symbolic structures}

Symbolic structures in science, and thus school science, address the use of representational forms, concepts, and systems for classifications as well as genres.

In SSC, the symbolic aspects of science are addressed in two main places. First, they are clarified in the section Basic Skills. This section, which describes the five basic skills, is an elaboration on the Norwegian Framework for Basic Skills. ${ }^{5}$ Second, basic skills are made explicit in the competence aims (see the examples in Table 2a, where pupils are to describe, explain, discuss, and use statistics). Being able to describe and explain phenomena empirically or theoretically are important aspects of being knowledgeable in science. The competence aims of the electromagnetism unit, shown in Table $2 \mathrm{a}$, deal implicitly with the many ways of expressing oneself in science, which are usually not limited to verbal expression. Thus, the aim requires working with several representations at the same time while assessing whether the explanation is appropriate (i.e. understanding the genre). Table $2 \mathrm{~b}$ also provides examples of how pupils are to transform and use different forms of representation (e.g., texts or empirical materials).

TEC does not state that the students themselves should be able to manage and integrate different representations in order to communicate efficiently. However, it emphasizes that students should be able to "facilitate science teaching that promotes all basic skills" (TEC, p. 67). It can be argued that the TEC indirectly requires students to adopt the "language of science" so that they can guide their pupils in the future. This argument can be substantiated by the emphasis on, for example, classifications ("names, attributes, and characteristics") without any problematizing of the classification schemes. Furthermore, TEC does not mention the genres of science, such as (various forms of) descriptions, explanations, or, for that matter, scientific reports. However, scientific concepts are explicitly included in several aims related to didactical skills.

In summary, in SSC, the symbolic aspects of science are made explicit through attention to genres and various representations. The emphasis on symbolic aspects can be regarded as leaning more toward Visions II and III: an understanding of the workings of the language of science is necessary if one is to address societal issues and individual life situations in which one uses scientific knowledge. In TEC, the symbolic aspects of science are implicit except for the emphasis on concepts. In other words, TEC has a more tacit approach to expressing oneself in the language of science, which can be argued as in alignment with Vision I.

\subsection{Syntactical structures}

\footnotetext{
${ }^{5}$ Developed by the Norwegian Directorate for Education and Training for use as a tool in developing and revising curricula. Since 2006, all subject-specific curricula in primary and secondary education are required to describe how basic skills contribute to developing pupils' competence.
} 
Syntactical structure involves the approaches used to address the substance of the courses. What types of approaches are used to describe "knowledgeability" and "knowledge work"? How is knowledge validated constructively and critically? The first part of this section presents a more detailed framework for analysing syntactical structures before presenting the findings. Didactical skills in TEC will be treated separately because they have no counterpart in SSC.

We apply two analytical dimensions of syntactical structure: knowledge approaches and validation of knowledge. Different possibilities for categorizing knowledge approaches (e.g., Bloom, 1956; Krathwohl, 2002). We chose a rather crude system for coding that is quite simple to apply. We identify three knowledge approaches:

- "to have" - to acquire knowledge (Sfard, 1998);

- "to use" - to apply knowledge-where knowledge is taken into the realm of the social to be re-verbalized (e.g., discussed, written) or used in a more concrete and practical manner (e.g., to make a physical object) (Sfard, 1998); and

- "to make" - to produce or create (new) knowledge (Paavola, Lipponen, \& Hakkarainen, 2004) -where knowledge is shaped through the processes of scientific inquiry, which can be based on literature studies and/or experiments or fieldwork (R. Duschl, 2008; Norris \& Phillips, 2008).

We do not consider the knowledge approach to be a hierarchical system progressing from easy to difficult because assessing the "degree of difficulty" would require more information on the types of problems. Validation of knowledge is an important part of the "knowledge society" (Jenkins, 2003), especially with regard to themes for which differences in position will necessitate assessing empirical and theoretical arguments (Kolstø, 2001). Validation depends on the traditions within scientific disciplines (Jenkins, 2013).

Knowledge approaches. In SSC's Purpose section, the approach to science might be summarized as "laws and theories of natural science are models of a complex reality [...] changed or developed through new observations, experiments, and ideas" (SSC, p. 1). In TEC's introduction, scientific knowledge is summed up as "see[ing] the scientific worldview as a cultural product, where observations, experiments, discussions, and theory gradually alter our knowledge" (TEC, p. 65). In both these excerpts, science is seen as a field of knowledge that is in continuous development, thus perhaps more aligned with Vision II than Vision I.

In SSC, the competence aims primarily describe and explain some (known) processes or phenomena. There is thus a strong orientation toward reproducing established knowledge. Moreover, there are many aims. The main area, The Budding Researcher, stresses the importance of both practical and theoretical work. The competence aims in Table $2 \mathrm{~b}$ emphasize "developing" questions and hypotheses as well as experiments. SSC also emphasizes the communication of science through its use of verbs, such as "talk about," "formulate," and "discuss." In TEC's learning outcomes concerning knowledge, there is 
overwhelming use of formulations such as "have knowledge about/in" and "be acquainted with" a science topic. In other words, TEC emphasizes acquiring knowledge. There is little mention of "discuss," "develop," "inquire," or "assess." The one aim dealing explicitly with epistemological issues is formulated as "know about" (see Table $2 b$ ).

Thus, the orientation toward science in both introductions can be summarized as seeing science as part of culture and as always developing. The SSC competence aims emphasize knowledge processes such as acquiring, using, and creating, the majority of which are categorized as acquiring. The TEC learning outcomes emphasize acquiring. None of the documents can be said to systematically promote action competence (Vision III), with the exception of one competency aim in SSC.

Validation of knowledge. In SSC, argumentation and discussion are seen as a part of developing pupils' scientific understanding. The pupil is not expected to assess or validate "pure" science subject matter. There is no use of the words "discuss" or "improve" in the competence aims dealing with established knowledge. However, when the topic is empirical investigations or sciencerelated issues in society, such as health or environmental issues, the pupils might assess and discuss information. In TEC, the validation of knowledge is connected to the student's own (practical) work and only partly to the knowledge in textbooks or other authoritative sources.

Thus, SSC expects pupils to validate knowledge with regard to experiments and science-related issues. TEC initiates the validation of results from experiments but does not state that students are to critically and constructively validate scientific knowledge. In other words, the objective of critically relating to science, seen as vital in Vision III, is missing in both documents.

Didactical skills. The approaches to didactics are varied in TEC. However, there are two recurring processes: "can use" and "can carry out." Didactics are thus mostly about using knowledge and not about making it. Some of the listed skills are oriented toward the pupils. One formulation illustrates this point: "the student can use scientific knowledge in conversations with pupils" (TEC, p. 67). There is no requirement that students need to "talk science" with peers or others. TEC states, "The education is to provide experiences with . . . didactical reflection" (TEC, p. 65); traditionally, reflection involves the assessment of knowledge and scrutinizing actions, but this is implicit rather than explicit in TEC.

In summary, there is a stark difference between the two curricula in their approaches to knowledge. SSC applies a broader range of approaches. In TEC, on the other hand, knowledge is to be acquired. Didactics are presented as skills, not knowledge. The validation of knowledge, in both documents, is connected to practical investigations, but SSC also makes explicit the need to validate (some) texts and sources of knowledge. 


\subsection{Value structures}

Value structure pertains to scrutinizing particular ways of viewing the nature of knowledge and what is worth learning and why. A quite common notion among some scientists and science educators, as well as among society, has been that science is "value-free" or "objective" (Corrigan, 2014). However, both science and curricula are human constructions and knowledge-seeking enterprises, and it is therefore important to explore the values that underpin science curricula. We base this particular analysis on Corrigan (2014), who argues that values in science and science education have both an epistemic and sociological dimension. We do, however, regard the two dimensions as empirically interwoven.

The nature of knowledge is explored through questions such as: What is scientific knowledge? What is seen as valuable knowledge to include in curricula? In the introductory parts of both documents, science is seen as both a discipline-specific and an interdisciplinary enterprise. Moreover, the documents introduce science as a social and cultural product that has developed through empirical and theoretical achievements. This implies that science is developed through inferences from empirical material as well as through argumentation, and it is through these processes that science gains its "objectivity" (Longino, 1990). In the competence aims and learning outcomes, however, both documents implicitly present scientific knowledge as true and uncontroversial. The competence aims and learning outcomes are derived from well-established science content. Thus, they convey a sense of permanent objectiveness.

Both documents explicitly advocate for sustainable development and the importance of knowing and caring for nature, which could - in itself - be connected to Vision III if it were connected to action competence. The SSC competency aim concerning environment shown in Table 2a links knowledge, argumentation, and possible actions. It is, however, the only aim with such a direct linkage. TEC appears to embrace a more normative approach to sustainable development, as there is an implicit link between knowing what is right and good and doing good. TEC states that teachers need knowledge about local and global environmental challenges, and "[T]hey have to be able to facilitate teaching that promotes pupils' love for nature and feeling of responsibility, which, over time, develops into knowledge and engagement with the environment" (TEC, p. 65). Thus, both documents express what might be called eco-friendliness but with very little problematizing of the values underlying the nature of knowledge for sustainable development.

Attitudes toward science can be seen as the answer to the questions: Why learn science? Why is scientific knowledge important for society and for individuals? What values are promoted as human qualities developed through science education?

On the societal level, SSC provides three main arguments for the value of teaching science: science is part of "our culture"; it shall provide "a basis for participating in processes in society" (SSC, p. 1); and, it shall provide a good 
basis for further learning and work. SSC advocates for science based on its role in the participation of individuals in a knowledge society, in addition to its role in enculturation. Moreover, SSC emphasizes attitudes that promote a balanced view of science: "Natural science shall also help children and young persons attain knowledge and form attitudes that will give them a well-balanced view of the interaction between nature, individuals, technology, society, and research" (SSC, p. 1). In the section on competence aims, this balanced position is not equally clear because there are few instances where such deliberations are required (see Table 2a). TEC argues for science and technology as a necessity for "our civilization" (TEC, p. 65), and scientific knowledge is presented as a crucial factor in the challenges "we" face both globally and locally. TEC thus argues that learning science is a necessary part of enculturation and contributes to meeting society's need for scientists. TEC learning outcomes signal a more technical attitude toward knowledge. Formulations such as "has knowledge about" and "is acquainted with" emphasize the acquisition of knowledge cognitively rather than knowledge as a basis for agency and specific actions.

In SSC's introduction, human qualities are described with words such as creativity, critical ability, openness, curiosity, and active participation. In the competence aims, human qualities are connected to the individual pupil and her/his varied approaches to, for the most part, an established body of knowledge. The pupils are also expected to work together, carrying out processes of science and making arguments and assessments related to their inquiries. In other words, emphasis is placed not only on cognitive values but also on values connected to social relations. Zeidler et al. (2016) levelled the criticism that analytical skills are emphasized at the expense of other types of reasoning, such as emotive reasoning, perspective-taking, and conscience. SSC seems to emphasize analytical skills in addition to promoting science as creative. In this way, the document omits the need to build perseverance or develop emotive reasoning and conscience. In TEC, the following attitudes are made explicit: curiosity, joy of discovery, and sense of wonder. In other words, to "learn" and to "do science" are coupled with only positive experiences. Moreover, TEC sees "love and responsibility" as a prerequisite or starting point for developing scientific knowledge (see citation above). The implicit entanglement of values and knowledge is not problematized. Moreover, in TEC, there is a focus on the individual student, and this student needs to mostly interact with his/her pupils, not with fellow students. The human qualities of a "good" teacher seem to be the ability to know and give an account of a specific body of knowledge as well as to facilitate wonder and curiosity.

In sum, both documents signal objectiveness with regard to the nature of knowledge and are thus more aligned with Vision I than with the more critical approaches advocated by Vision II and especially Vision III. Both documents are concerned with science as enculturation but otherwise provide different arguments for learning science. Both documents promote the idea that by working with school science, young people will develop the human qualities of creativity and wonder, which the teacher is to cultivate in the pupils. However, 
the competence aims in SSC emphasize analytical qualities, and the learning outcomes in TEC emphasize the ability to acquire.

\subsection{Summing up positions on scientific literacy}

In this section, we summarize the analysis and provide a perspective on epistemic tensions and alignments within and between the two documents.

In comparing the documents, the first analytic impression is a seemingly strong epistemic alignment between the curricula, as both relate to much of the same established scientific knowledge. However, there are differences, particularly in their symbolic and syntactical structures.

The main epistemic tensions within each of the two curricula are similar. The purpose in SSC is oriented toward seeing science as part of society, whereas the competence aims give prominence to learning the established body of knowledge-although there are aims related to NOS and science-related issues in society. In TEC, this tension is more obvious, as there is even less emphasis in the learning outcomes on NOS and science-related issues in society. Moreover, there are internal tensions in both documents regarding environmental values, which are promoted strongly in the introductions and followed up with weaker formulations in the competence aims and learning outcomes. These internal tensions in the documents can be regarded as the competence aims and learning outcomes leaning more toward Vision I while the introductions lean more toward Vision II.

Table 3. Epistemic alignments and tensions between SSC and TEC

\begin{tabular}{|c|c|c|}
\hline & $\begin{array}{l}\text { Alignments between SSC } \\
\text { and TEC }\end{array}$ & $\begin{array}{l}\text { Tensions between SSC and } \\
\text { TEC }\end{array}$ \\
\hline $\begin{array}{l}\text { Relationships and } \\
\text { priorities among } \\
\text { knowledge areas } \\
\text { (Organizational } \\
\text { structure) }\end{array}$ & $\begin{array}{l}\text { Science content grouped } \\
\text { primarily according to the } \\
\text { disciplines of science }\end{array}$ & $\begin{array}{l}\text { SSC is partly vertical, where } \\
\text { topics require knowledge from } \\
\text { a previous stage; TEC is } \\
\text { horizontal and agglomerative }\end{array}$ \\
\hline $\begin{array}{lr}\text { Selection } & \text { of } \\
\text { knowledge } & \text { and } \\
\text { skills } & \\
\text { (Substantial } & \\
\text { structure) } & \end{array}$ & $\begin{array}{l}\text { Majority of aims/outcomes } \\
\text { involve the body of } \\
\text { knowledge of science, facts, } \\
\text { and laws }\end{array}$ & $\begin{array}{l}\text { SSC emphasizes learning about } \\
\text { NOS and (partly) science- } \\
\text { related issues in society; TEC } \\
\text { does so to a much lesser extent }\end{array}$ \\
\hline $\begin{array}{l}\text { Communication of } \\
\text { knowledge } \\
\text { (Symbolic structure) } \\
\end{array}$ & & $\begin{array}{l}\text { SSC } \\
\text { representational forms and } \\
\text { genres; TEC does not }\end{array}$ \\
\hline $\begin{array}{l}\text { Knowledge } \\
\text { approaches }\end{array}$ & $\begin{array}{llr}\text { Introduction: } & \text { science is a } \\
\text { cultural product } & \text { in } \\
\text { development } & & \end{array}$ & $\begin{array}{l}\text { Aims: SSC has varied } \\
\text { approaches to knowledge-to } \\
\text { have, participate, and produce; } \\
\text { TEC requires acquiring } \\
\text { scientific knowledge and using } \\
\text { teaching skills. }\end{array}$ \\
\hline
\end{tabular}




\begin{tabular}{|l|l|l|}
\hline $\begin{array}{l}\text { Validation of of } \\
\text { knowledge } \\
\text { (Syntactical } \\
\text { structure) }\end{array}$ & $\begin{array}{l}\text { Validation of } \\
\text { investigations, such as } \\
\text { experiments }\end{array}$ & $\begin{array}{l}\text { SSC requires that pupils assess } \\
\text { and validate several issues; } \\
\text { TEC does not }\end{array}$ \\
\hline $\begin{array}{l}\text { Embedded values } \\
\text { regarding the nature } \\
\text { of knowledge and } \\
\text { attitudes toward } \\
\text { science } \\
\text { (Value structure) }\end{array}$ & $\begin{array}{l}\text { Scientific knowledge is true } \\
\text { and unproblematic; doing } \\
\text { science provides positive } \\
\text { experiences }\end{array}$ & $\begin{array}{l}\text { SSC and TEC provide partly } \\
\text { different arguments for why } \\
\text { we should learn science; SSC } \\
\text { advocates a somewhat more } \\
\text { balanced relationship between } \\
\text { science and society }\end{array}$ \\
\hline
\end{tabular}

Table 3 shows epistemic alignments and tensions between the two curricula. There is considerable overlap in the selection of the body of knowledge. Furthermore, both documents advocate the values of eco-friendliness and positive experiences (curiosity, creativity, etc.). These values are not problematized. Finally, both curricula emphasize validating the experimental results of students'/pupils' own practical investigations in the laboratorymeaning science processes.

There are, however, some major epistemic tensions between the documents. The organization of the body of knowledge differs between the two. While SSC has a mostly cumulative knowledge structure, where one segment is a building block for the next, knowledge in TEC is organized in agglomerative segments. Substantively, the two curricula vary little, as both have a strong focus on the scientific cannon; however, SSC also puts some emphasis on NOS and on the complex interactions among science, technology, and society. In regard to how knowledge should be communicated, SSC emphasizes genres and representational forms, while TEC does not. SSC promotes varied approaches to knowledge, as well as assessment and validation of some knowledge sources. TEC, on the other hand, lacks variation in approaches to knowledge and defines science as knowledge and teaching as skills. Moreover, TEC leaves out assessment and validation of knowledge. Finally, SSC provides arguments for the individual person's need for science, whereas TEC argues for the need for science in a knowledge society.

These tensions between the two documents reveal their different leanings regarding scientific literacy. SSC promotes a position on scientific literacy that is partly aligned with Vision II and partly aligned with Vision I. The number and content of competence aims reflect a more traditional position toward knowledge (Voogt \& Roblin, 2012) - that is, Vision I. There are a few elements in SSC that lean toward Vision III and action competence. TEC is even more clearly oriented toward Vision I and seems to strive for "scientist-science," where the processes of scientific knowledge are treated implicitly. 


\section{Developing pupils' scientific literacy: Possible challenges for prospective science teachers}

The analysis in this article has revealed that the two science curricula differ in their positions on scientific literacy. TEC is oriented toward Vision I, whereas SSC draws on both Vision I and Vision II, perhaps with greater weight on Vision I. Tendencies toward Vision III are totally absent from TEC and mostly absent from SSC. The question then becomes whether intentions regarding scientific literacy in the teacher education curriculum could lay the foundation for prospective teachers to develop their pupils' scientific literacy.

There is no doubt that science teachers need to know the body of scientific knowledge they are teaching (Davis et al., 2006). However, we argue that prospective science teachers (educated based on the curriculum analysed herein) might be ill-equipped to address vital epistemic aspects of science, which could mean that the school science curriculum is less likely to come to fruition and achieve its goals. To be able to conduct reliable science investigations, teachers need to know how to make those investigations reliable and why doing so is important, that is, they must emphasize the epistemic dimension (Osborne, 2014). There is also a question of whether the substantial body of knowledge in TEC and its emphasis on acquisition will result in prospective teachers that are enculturated in "teaching as telling" and "activities that work," which might result in difficulty obtaining the necessary depth in the conceptual and factual bases for teaching science.

Superficial attentiveness to the communication of science and validation of knowledge might lead to an unreflective view on the authoritarian voice of the body of knowledge, leading to its uncritical adoption (Lemke, 1990). The lack of explicit attention to genres, as well as the syntactical structure of science, might create a problem for pupils' scientific literacy (Norris \& Phillips, 2003), as might the lack of attention to representations (Tytler, Prain, \& Hubber, 2013). Prospective teachers' blurry conceptions of basic genres might well lead to problems when pupils must give descriptions and explanations (Braaten \& Windschitl, 2011) - the two most frequent knowledge processes in SSC. The language of science is not easy (Halliday, 2004), and being able to use it with proficiency is necessary if one is to gain action competence or be able to participate in non-superficial discussions on science-related issues in society.

Russ (2014) makes a strong argument that the epistemology of (professional) science and the epistemology of school science cannot be seen as the same. This implies that in order to discuss NOS, teachers need to be aware of similarities and differences between professional science and school science. Engaging in scientific practices requires an understanding of the tentativeness of science and requires the ability to consider alternative explanations (Crawford, 2007, 2014). There is thus a strong coupling between balanced perspectives on NOS and scientific processes. These are difficult perspectives to translate into classroom practice (Lederman \& Lederman, 2014); however, a teacher education program that emphasizes NOS would seem to give teachers the ability to both plan for and improvise NOS in settings with their pupils (Herman, Clough, \& Olson, 
2013). If the prospective teacher has little knowledge of NOS, it is even less likely that she/he will include such perspectives in science teaching. There are indications that if the process aspects in school science are made explicit, then pupils will learn about NOS (Deng, Chen, Tsai, \& Chai, 2011). In other words, if these aspects of science are treated implicitly through practical work or inquiry, it is very likely that pupils will obtain at least a limited understanding of science as an epistemic enterprise. One would perhaps have expected TEC to address these issues explicitly, as they have been well-known issues in the field of science education for a long time (e.g. Hodson, 1993). When TEC emphasizes curiosity, joy of discovery, and sense of wonder rather than NOS and the language of science, the overall impression is that it favours a science subject matter that is rich in experience but lacks the balanced approaches to science for which SSC strives.

As has long been argued, science education must prepare individuals for engagement in local and global technological and environmental issues (Hodson, 2011; Mogensen \& Schnack, 2010; Roth \& Barton, 2004). In the curricula analysed here, values such as eco-friendliness are seemingly held in high regard. However, there is little coupling of competence aims and learning outcomes with action, nor is there discussion of how to handle disagreements concerning possible action. One may question whether the lack of problematization concerning what is "good" might lead to (unwanted) normativity or perceived objectivity (Sund \& Öhman, 2014). This can indeed be seen as problematic, as, on the one hand, one of the main roles of education is to transmit values that are seen as worthwhile and important in a society; on the other hand, education ought to promote democracy and multiple views.

The epistemic dimension of the documents analysed here have implications for the respective learners, although there is definitely not a simple cause-effect relationship between the curriculum document and the actual learning outcome (Goodlad, 1979), and the coherence that students seek might be far from the intentions of the curriculum (Sikorski \& Hammer, 2017). SSC seems to prioritize the growth of pupils into citizens who can address science constructively and critically, as well as into adults who enter science-related careers. School science prepares pupils for both scientific knowledge production and civic participation. However, such a dual position is difficult to maintain and teach (Smith \& Gunstone, 2009) . TEC promotes a vision connected to educating scientists; it seems to convey the intention that the teacher students are to become "insiders" in science (Feinstein, 2011). However, teacher students cannot be expected to become real insiders in science considering the time constraints of the course and the students' subject matter foundation. This raises the problem of the prospective teachers' ability to teach their pupils to participate in and be included in school scientific discourse, as well to address science-related and environmental issues. 


\section{Limitations and directions for future research}

One major limitation of this study is that it is an analysis of national curricula documents. Even if these documents are legally binding for local teacher education institutions and schools, they are adapted and transformed into local curricula and lesson plans. In other words, it is possible that individual teacher education institutions have local curricula and lesson plans that are more or less aligned with the school science curricula than are the national curricula. How the national documents are adapted to local conditions would be an interesting topic of research. Moreover, discrepancies inherently exist between practice and curricula documents. The practice will rely on additional factors such as students' prior knowledge, teachers' beliefs (Jones \& Leagon, 2014), alignment between textbooks and curricula, and the knowledge practices that are constructed jointly by teachers and students/pupils. Curricula have "slow" impact-it takes time for teachers to adapt to new curricula. Earlier research has explored the school (science) curricula (Sivesind, 2012) but not science teacher education. Inherent in the missing evaluative research is the challenge of the frequent reforms and the discontinuous and heterogeneous takes on knowledge represented in each reform.

\section{Concluding remarks}

This analysis of two related curricular documents - The National Guidelines for Differentiated Teacher Education Programs (Kunnskapsdepartementet [Norwegian Ministry of Education and Research], 2011) and The Curriculum for School Science (Utdanningsdirektoratet [Norwegian Directorate for Education and Training], 2013) - has provided the opportunity to compare and discuss how they position themselves on scientific literacy. This analytical framework provides an opportunity to go beyond superficial or surface alignment of the two documents, that is, alignment primarily in the selection of knowledge and skills (i.e. substantive structure). The analysis has revealed differences concerning value and syntactical structures that are not otherwise easily detected. We thus conclude that this approach is advantageous to identifying gaps between teacher education and science education curricula. These gaps might impose constraints on achieving the overall aim of scientific literacy, and we thus believe it is necessary to continue to discuss the nature of the relationship between the two forms of science education-and what it ought to be-in order to enable the education of scientifically literate pupils.

\section{References}

Abd-El-Khalick, F. (2011). Nature of science in science education: Toward a coherent framework for synergistic research and development. In B. J. Fraser, K. Tobin, \& C. J. McRobbie (Eds.), Second international handbook of science education (Vol. 2, pp. 1041-1060). Dordrecht: Springer.

Aikenhead, G., Orpwood, G., \& Fensham, P. (2011). Scientific literacy for a knowledge society. In C. Linder, L. Östman, D. A. Roberts, P.-O. Wickman, G. Erickson, \& A. MacKinnon (Eds.), Exploring the landscape of scientific literacy (pp. 28-44). Oxon: Routledge. 
Appleton, K., \& Kindt, I. (2002). Beginning elementary teachers' development as teachers of science. Journal of Science Teacher Education, 13(1), 4361.https://doi.org/10.1023/a:1015181809961

Bernstein, B. (2000). Pedagogy, symbolic control, and identity: Theory, research, critique. Oxford: Rowman \& Littlefield Publishing.

Bianchini, J. A. (2012). Teaching while still learning to teach: Beginning science teachers' views, experiences, and classroom practices. In B. J. Fraser, K. G. Tobin, \& C. J. McRobbie (Eds.), Second international handbook of science education (Vol. 1, pp. 389_ 399). Dordrecht: Springer.

Bloom, B. S. e. (1956). Taxonomy of educational objectives: Handbook I: Cognitive domain (Vol. 19). London: Longman.

Braaten, M., \& Windschitl, M. (2011). Working toward a stronger conceptualization of scientific explanation for science education. Science Education, 95(4), 639-669 https://doi.org/10.1002/sce.20449

Cochran-Smith, M., \& Villegas, A. M. (2015). Framing teacher preparation research: An overview of the field, part 1. Journal of Teacher Education, 66(1), 7-20 https://doi.org/10.1177/0022487114549072

Collins, H., French, S., Millar, R., Osborne, J., Vinen, W. F., \& Wright, P. (2000). Forum: Beyond 2000. Studies in Science Education, 35(1), 167-173. https://doi.org/10.1080/03057260008560160

Corrigan, D. (2014). Curriculum and values. In R. Gunstone (Ed.), Encyclopedia of science education (pp. 1-4). Dortrecht: Springer.

Crawford, B. A. (2007). Learning to teach science as inquiry in the rough and tumble of practice. Journal of Research in Science Teaching, 44(4), 613-642. https://doi.org/10.1002/tea.20157

Crawford, B. A. (2014). From inquiry to scientific practices in the science classroom. In N. G. Lederman \& S. K. Abell (Eds.), Handbook of research on science education. Oxon: Routledge.

Darling-Hammond, L. (2006). Constructing 21st-century teacher education. Journal of Teacher Education, 57(3), 300-314. https://doi.org/10.1177/0022487105285962

Davis, E. A., Petish, D., \& Smithey, J. (2006). Challenges new science teachers face. Review of Educational Research, 76(4), 607-651. https://doi.org/10.3102/00346543076004607

Deng, F., Chen, D.-T., Tsai, C.-C., \& Chai, C. S. (2011). Students' views of the nature of science: A critical review of research. Science Education, 95(6), 961-999. https://doi.org/10.1002/sce.20460

Dressel, P. L., \& Marcus, D. (1982). On teaching and learning in college. San Francisco, CA: Jossey-Bass.

Duschl, R. (2008). Science education in three-part harmony: Balancing conceptual, epistemic, and social learning goals. Review of Research in Education, 32(1), 268 291. https://doi.org/10.3102/0091732x07309371

Duschl, R. A., \& Grandy, R. E. (2008). Teaching scientific inquiry: Recommendations for research and implementation. Rotterdam: Sense Publishers.

European Parliament Council of the European Union. (2006). Recommendation of the European Parliament and of the Council of 18 December 2006 on key competences for lifelong learning. Retrieved from http://eur-lex.europa.eu/legalcontent/EN/ALL/;jsessionid=x4lFTnsMyRsnsnjBgqnwlsN5jDgF1NkhrHKhvQ4 09tGyYsTkxk1N!632333948?uri=CELEX:32006H0962

Eurydice Education Audiovisual and Culture Executive Agency. (2011). Science education in Europe: National policies, practices and research. Retrieved from http://eacea.ec.europa.eu/education/eurydice/documents/thematic_reports/1 33en.pdf 
Fairclough, N. (2003). Analysing discourse. Textual analysis for social research. Oxon: Routledge.

Feinstein, N. W. (2011). Salvaging science literacy. Science Education, 95(1), 168-185. https://doi.org/10.1002/sce.20414

Fensham, P. (2013). The science curriculum: The decline of expertise and the rise of bureaucratise. Journal of Curriculum Studies, 45(2), 152-168. https://doi.org/10.1080/00220272.2012.737862

Goodlad, J. I. (1979). Curriculum inquiry: The study of curriculum practice. New York: McGraw-Hill.

Halliday, M. A. K. (2004). The language of science. London: Continuum.

Harlen, W. e. (2010). Principles and big ideas of science education. Retrieved from https://www.ase.org.uk/documents/principles-and-big-ideas-of-scienceeducation/

Herman, B. C., Clough, M. P., \& Olson, J. K. (2013). Teachers' nature of science implementation practices 2-5 years after having completed an intensive science education program. Science Education, 97(2), 271-309. https://doi.org/10.1002/sce.21048

Hodson, D. (1993). Re-thinking old ways: Toward a more critical approach to practical work in school science Studies in Science Education, 22, 85-142. https://doi.org/10.1080/03057269308560022

Hodson, D. (2003). Time for action: Science education for an alternative future. International Journal of Science Education, 25(6), 645-670. https://doi.org/10.1080/09500690305021

Hodson, D. (2011). Looking to the future. Building a curriculum for social activism. Rotterdam: Sense Publishers.

Hofstein, A., \& Kind, P. M. (2011). Learning in and from science laboratories. In B. J. Fraser, K. Tobin, \& C. J. McRobbie (Eds.), Second international handbook of science education (Vol. 1, pp. 189-207). Dordrecht: Springer.

Hopmann, S. (2007). Restrained teaching: The common core of Didaktik. European Educational Research Journal, 6(2), 109-124. https://doi.org/10.2304/eerj.2007.6.2.109

Jenkins, E. (2003). School science: Too much, too little, or a problem with science itself? Canadian Journal of Math, Science \& Technology Education, 3(2), 269-274. https://doi.org/10.1080/14926150309556564

Jenkins, E. (2013). The 'nature of science' in the school curriculum: the great survivor. $\begin{array}{llll}\text { Journal of curriculum } & \text { studies, } & 45(2), & 132-151 .\end{array}$ https://doi.org/10.1080/00220272.2012.741264

Jones, M. G., \& Leagon, M. (2014). Science teacher attitudes and beliefs: Reforming practice. In N. G. Lederman \& S. K. Abell (Eds.), Handbook of research in science education (Vol. II). New York: Routledge.

Knain, E. (2015). Scientific literacy for participation: A systemic functional approach to analysis of school science discourses. Rotterdam: Sense.

Kolstø, S. D. (2001). Scientific literacy for citizenship: Tools for dealing with the science dimension of controversial socioscientific issues. Science Education, 85(3), 291309. https:// doi.org/10.1002/sce.1011

Krathwohl, D. R. (2002). A revision of Bloom's taxonomy: An overview. Theory into Practice, 41(4), 212-218. https:// doi.org/10.1177/107621758100400412

Kunnskapsdepartementet [Norwegian Ministry of Education and Research]. (2009). Nasjonalt kvalifikasjonsrammeverk for høyere utdanning. Oslo. Retrieved from http://www.regjeringen.no/en/dep/kd/tema/hoyere_utdanning/nasjonaltkvalifikasjonsrammeverk.html?id=564809

Kunnskapsdepartementet [Norwegian Ministry of Education and Research]. (2011). Nasjonale retningslinjer for grunnskolelærerutdanningen. Oslo. Retrieved from 
http://www.regjeringen.no/en/dep/kd/documents/legislation/legalguidelines $/ 2010 /$ national-guidelines-for-differentiated-t.html?id=640249

Kunnskapsdepartementet [Norwegian Ministry of Education and Research]. (2015). Tett på realfag. Nasjonal strategi for realfag $i$ barnehagen og grunnoplæringen (2015-2019) [Focus on science and mathematics. National strategy for kindergarten and school]. Oslo.

Retrieved

from

https://www.regjeringen.no/contentassets/869faa81d1d740d297776740e67e3e6 5/kd_realfagsstrategi.pdf

Lattuca, L. R., \& Stark, J. S. (2009). Shaping the college curriculum: Academic plans in context. San Francisco, CA: Jossey-Bass.

Lederman, N. G., \& Lederman, J. S. (2012). Nature of scientific knowledge and scientific inquiry: Building instructional capacity through professional development. In B. J. Fraser, K. G. Tobin, \& C. J. McRobbie (Eds.), Second international handbook of science education (Vol. 1, pp. 335-359). Dordrecht: Springer.

Lederman, N. G., \& Lederman, J. S. (2014). Research on teaching and learning of nature of science. In N. G. Lederman \& S. K. Abell (Eds.), Handbook of research on science education (Vol. 2, pp. 600-620). New York: Routledge.

Lemke, J. (1990). Talking science: Language, learning, and values. Norwood, NJ: Ablex Publishing Corporation.

Liu, X. (2013). Expanding notions of scientific literacy: A reconceptualization of aims of science education in the knowledge society. In N. Mansour \& R. Wegerif (Eds.), Science education for diversity (pp. 23-39). Dordrecht: Springer.

Longino, H. E. (1990). Science as social kowledge: Values and objectivity in scientific inquiry. Princeton, NJ: Princeton University Press.

Loughran, J. J. (2014). Developing understandings of practice: Science teacher learning. In N. G. Lederman \& S. K. Abell (Eds.), Handbook of research on science education. (Vol. 2, pp. 811-829). Oxon: Routledge.

Melville, W. (2008). Mandated curriculum change and a science department: A superficial language convergence? Teaching and Teacher Education, 24(5), 11851199, https://doi.org/10.1016/j.tate.2007.03.004

Mogensen, F., \& Schnack, K. (2010). The action competence approach and the 'new'discourses of education for sustainable development, competence and quality criteria. Environmental Education Research, 16(1), 59-74. https://doi.org/10.1080/13504620903504032

Muller, J. (2009). Forms of knowledge and curriculum coherence. Journal of Education and work, 22(3), 205-226. https:// doi.org/10.1080/13639080902957905

National Research Council. (2012). A framework for K-12 science education: Practices, crosscutting themes, and core ideas. Washington, DC: National Academies Press.

Norris, S., \& Phillips, L. M. (2003). How literacy in its fundamental sense is central to scientific literacy. Science Education, 87(2), 224-240. https://doi.org/10.1002/sce.10066

Norris, S., \& Phillips, L. M. (2008). Reading as inquiry. In R. A. Duschl \& R. E. Grandy (Eds.), Teaching Scientific Inquiry (pp. 233-261). Rotterdam: Sense Publishers.

Olson, J. K., Tippett, C. D., Milford, T. M., Ohana, C., \& Clough, M. P. (2015). Science teacher preparation in a North American context. Journal of Science Teacher Education, 26(1), 7-28. https://doi.org/10.1007/s10972-014-9417-9

Organisation for Economic Co-operation and Development. (2012a). Education Today 2013. In. http://dx.doi.org/10.1787/edu_today-2013-en

Organisation for Economic Co-operation and Development. (2012b). PISA 2015 Item Submission Guidelines: Scientific Literacy. Vol. 2014. Retrieved from http://www.oecd.org/pisa/pisaproducts/Submission-Guidelines-Science.pdf

Organisation for Economic Co-operation and Development. (2016). PISA 2015 Results (Volume II). http://dx.doi.org/10.1787/9789264267510-en 
Osborne, J. (2014). Teaching scientific practices: Meeting the challenge of change. Journal of Science Teacher Education, 25(2), 177-196. https://doi.org/10.1007/s10972-0149384-1

Paavola, S., Lipponen, L., \& Hakkarainen, K. (2004). Models of innovative knowledge communities and three metaphors of learning. Review of Educational Research, 74(4), 557-576. https://doi.org/10.3102/00346543074004557

Phenix, P. (1986). Realms of meaning: A philosophy of the curriculum for general education. New York: McGraw-Hill.

Roberts, D. A. (1988). What counts as science education? In P. Fensham (Ed.), Developments and dilemmas in science education (pp. 27-54). London: Falmer Press.

Roberts, D. A. (2007). Scientific literacy/science literacy. In S. K. Abell \& N. G. Lederman (Eds.), Handbook of research in science education (pp. 729-780). Oxon: Routledge.

Roberts, D. A., \& Bybee, R. W. (2014). Scientific literacy, science literacy, and science education. In N. G. Lederman \& S. K. Abell (Eds.), Handbook of research on science education (pp. 545-558). Oxon: Routledge.

Roth, W.-M., \& Barton, A. C. (2004). Rethinking scientific literacy. New York, NY: Routledge.

Russ, R. S. (2014). Epistemology of science vs. epistemology for science. Science Education, 98(3), 388-396. https:// doi.org/10.1002/sce.21106

Russell, T., \& Martin, A. K. (2014). Learning to teach science. In N. G. Lederman \& S. K. Abell (Eds.), Handbook of research on science education (Vol. II, pp. 871-888). Oxon: Routledge.

Sadler, T. D., \& Zeidler, D. L. (2009). Scientific literacy, PISA, and socioscientific discourse: Assessment for progressive aims of science education. Journal of Research in Science Teaching, 46(8), 909-921. https://doi.org/10.1002/tea.20327

Sfard, A. (1998). On two metaphors for learning and the dangers of choosing just one. Educational Researcher, 25(2), 4-13. https:// doi.org/10.2307/1176193

Sikorski, T. R., \& Hammer, D. (2017). Looking for coherence in science curriculum. Science Education, 00, 1-15. doi:10.1002/sce.21299

Sivesind, K. (2012). Kunnskapsløftet: Implementering av nye læreplaner $i$ reformen. Synteserapport fra evalueringen av Kunnskapsløftet [Knowledge promotion: Implementation of the new curricula. A report synthesising the evaluation of knowledge promotion]. Retrieved from https://www.udir.no/tall-og-forskning/finnforskning/rapporter/kunnskapsloftet-implementering-av-nye-lareplaner-ireformen/

Smith, D. V., \& Gunstone, R. F. (2009). Science curriculum in the market liberal society of the twenty-first century: 'Re-visioning' the idea of science for all. Research in Science Education, 39(1), 1-16. https://doi.org/10.1007/s11165-007-9069-2

Sund, L., \& Öhman, J. (2014). On the need to repoliticise environmental and sustainability education: Rethinking the postpolitical consensus. Environmental Education Research, 20(5), 639-659. https:// doi.org/10.1080/13504622.2013.833585

Thomson, N., \& Tippins, D. J. (2013). Envisioning science teacher preparation for twentyfirst-century classrooms for diversity: Some tensions. In N. Mansour \& R. Wegerif (Eds.), Science Education for Diversity (pp. 231-249). Dordrecht: Springer.

Tytler, R., Prain, V., \& Hubber, P. (2013). Constructing representations to learn in science. Rotterdam: Sense.

Utdanningsdirektoratet [Norwegian Directorate for Education and Training]. (2013). Lxreplan $i$ naturfag [Curriculum for school science]. Retrieved from http://www.udir.no/k106/NAT1-03/.

Veel, R. (2000). Learning how to mean - scientifically speaking: Apprenticeship into scientific discourse in the secondary school. In F. Christie \& J. R. Martin (Eds.), 
Genre and institutions - social processes in the workplace and school (pp. 161-195). London: Continuum.

Voogt, J., \& Roblin, N. P. (2012). A comparative analysis of international frameworks for 21st century competences: Implications for national curriculum policies. Journal of Curriculum Studies, 299-321. https://doi.org/10.1080/00220272.2012.668938

Wallace, C. S. (2012). Authoritarian science curriculum standards as barriers to teaching and learning: An interpretation of personal experience. Science Education, 96(2), 291-310. https://doi.org/10.1002/sce.20470

Young, M. (2013). Overcoming the crisis in curriculum theory: a knowledge-based approach. Journal of Curriculum Studies, 45(2), 101-118. https://doi.org/10.1080/00220272.2013.764505

Zeidler, D. L., Herman, B. C., Clough, M. P., Olson, J. K., Kahn, S., \& Newton, M. (2016). Humanitas emptor: Reconsidering recent trends and policy in science teacher education. Journal of Science Teacher Education, 27(5), 465-476. https://doi.org/10.1007/s10972-016-9481-4 